Article

\title{
Serum Magnesium Concentrations in the Canadian Population and Associations with Diabetes, Glycemic Regulation, and Insulin Resistance
}

\author{
Jesse Bertinato ${ }^{1,2, *}$, Kuan Chiao Wang ${ }^{3}$ and Stephen Hayward ${ }^{3}$ \\ 1 Nutrition Research Division, Food Directorate, Health Products and Food Branch, Health Canada, \\ Sir Frederick G. Banting Research Centre, 251 Sir Frederick Banting Driveway, Ottawa, \\ ON K1A 0K9, Canada \\ 2 Department of Biochemistry, Microbiology and Immunology, University of Ottawa, Ottawa, \\ ON K1H 8M5, Canada \\ 3 Bureau of Food Surveillance and Science Integration, Food Directorate, Health Products and Food Branch, \\ Health Canada, Ottawa, ON K1A 0K9, Canada; \\ kuan.chiao.wang@hc-sc.gc.ca (K.C.W.); stephen.hayward@hc-sc.gc.ca (S.H.) \\ * Correspondence: jesse.bertinato@hc-sc.gc.ca; Tel.: +1-613-957-0924; Fax: +1-613-946-6212
}

Received: 26 January 2017; Accepted: 14 March 2017; Published: 17 March 2017

\begin{abstract}
Total serum magnesium (Mg) concentration (SMC) is commonly used to assess $\mathrm{Mg}$ status. This study reports current SMCs of Canadians and their associations with demographic factors, diabetes, and measures of glycemic control and insulin resistance using results from the Canadian Health Measures Survey cycle 3 (2012-2013). Associations were examined in adults aged 20-79 years using linear mixed models. Mean SMCs and percentile distributions for 11 sex-age groups between 3 and 79 years $(n=5561)$ are reported. SMCs were normally distributed and differences $(p<0.05)$ among sex and age groups were small. Between $9.5 \%$ and $16.6 \%$ of adult sex-age groups had a SMC below the lower cut-off of a population-based reference interval $\left(0.75-0.955 \mathrm{mmol} \cdot \mathrm{L}^{-1}\right)$ established in the United States population as part of the NHANES I conducted in 1971-1974. Having diabetes was associated with 0.04 to $0.07 \mathrm{mmol} \cdot \mathrm{L}^{-1}$ lower SMC compared to not having diabetes in the various models. Body mass index, glycated hemoglobin, serum glucose and insulin concentrations, and homeostatic model assessment of insulin resistance were negatively associated with SMC. This is the first study to report SMCs in a nationally representative sample of the Canadian population. A substantial proportion of Canadians are hypomagnesaemic in relation to a population-based reference interval, and SMC was negatively associated with diabetes and indices of glycemic control and insulin resistance.
\end{abstract}

Keywords: Canada; diabetes; glycemic regulation; homeostatic model assessment of insulin resistance; serum magnesium concentration

\section{Introduction}

Magnesium $(\mathrm{Mg})$ is a mineral nutrient that functions as a catalytic co-factor and structural component of enzymes and plays an important role as a calcium antagonist [1]. Mg is essential for many biological processes including the synthesis of organic molecules, cell proliferation, energy production, muscle contraction and relaxation, bone development, mineral metabolism, and glucose homeostasis [1-4]. In North America, $\mathrm{Mg}$ intakes fall short of dietary recommendations for a large segment of the population [5-7]. However, the extent of $\mathrm{Mg}$ deficiency in the general population and related health risks are unclear because of the uncertainty regarding $\mathrm{Mg}$ intakes needed for optimal health. This is underscored by the large differences in recommended intakes for 
Mg established by different scientific bodies [8-10]. In addition, current information on $\mathrm{Mg}$ status of the North American population is lacking.

Total serum $\mathrm{Mg}$ concentration is the most widely used nutritional biomarker for assessing $\mathrm{Mg}$ status [1,11,12]. A recent meta-analysis of randomized controlled trials showed that serum (or plasma) $\mathrm{Mg}$ concentrations were significantly increased by oral $\mathrm{Mg}$ supplementation in a doseand time-dependent manner [13]. Notably, little or no change in serum Mg was observed with higher baseline circulating $\mathrm{Mg}$ concentrations. Together, these results suggest that serum $\mathrm{Mg}$ concentrations can provide meaningful information on $\mathrm{Mg}$ status.

Information on serum $\mathrm{Mg}$ concentrations in the Canadian or United States populations from nationally-representative health surveys is limited. The last national estimates were based on data collected over 40 years ago in the first National Health and Nutrition Examination Survey (NHANES I) conducted in the United States between 1971 and 1974 [14]. These estimates were used to establish a population-based reference interval for adults of $0.75-0.955 \mathrm{mmol} \cdot \mathrm{L}^{-1}$. Based on this reference interval, a serum $\mathrm{Mg}$ concentration below $0.75 \mathrm{mmol} \cdot \mathrm{L}^{-1}$ is usually defined as hypomagnesaemia (low serum $\mathrm{Mg}$ concentration).

Low $\mathrm{Mg}$ intakes and/or serum $\mathrm{Mg}$ concentrations have been associated with a number of diseases and health conditions including hypertension [15,16], sudden cardiac death $[17,18]$, reduced bone mineral density [19], cardiovascular disease events [20,21], and colorectal cancer [22,23]. Poor Mg status may also impair growth of lean body mass [24] and decrease physical performance [25]. Diabetes (both type 1 and type 2) is the most common metabolic disorder associated with $\mathrm{Mg}$ deficiency [26-30], with reported incidence rates of hypomagnesaemia in diabetics as high as $13.5 \%-47.7 \%$ [27]. Multiple factors likely contribute to the hypomagnesaemia, including increased $\mathrm{Mg}$ loss through excretion by the kidneys. The higher renal $\mathrm{Mg}$ excretion is caused by reduced tubular $\mathrm{Mg}$ reabsorption resulting from glucose-induced osmotic diuresis and possibly insulin resistance [27,31]. Serum $\mathrm{Mg}$ has been negatively associated with fasting glucose and insulin concentrations and glycated hemoglobin $\left(\mathrm{HbA}_{1 \mathrm{c}}\right)$, a measure of long-term glycemic control [32-34]. Negative associations have also been reported with indirect indices of insulin resistance including quantitative insulin sensitivity check index (QUICKI), homeostatic model assessment of insulin resistance (HOMA-IR), and McAuley's index $[32,35]$.

Nationally-representative data are preferred over non-national data for the development of nutrition policies and regulations. National estimates of serum $\mathrm{Mg}$ concentrations have never been reported for Canadians. The primary objective of this study was to report current national estimates of serum $\mathrm{Mg}$ concentrations for the Canadian population for ages 3-79 years using results from the Canadian Health Measures Survey (CHMS) cycle 3 conducted between 2012 and 2013. In Canada, the high prevalence of obesity [36] and co-morbidities such as insulin resistance and diabetes [37] may have a negative effect on the $\mathrm{Mg}$ status of the population. Thus, secondary analyses were performed to examine population-level associations between serum $\mathrm{Mg}$ concentrations and demographic factors, diabetes, and measures of glycemic regulation and insulin resistance in adults in order to add to our understanding of subpopulations at increased risk for $\mathrm{Mg}$ deficiency.

\section{Materials and Methods}

\subsection{Survey Design}

The CHMS is a cross-sectional, population-based survey that collects health information through a household interview and direct physical measures. The CHMS used a multi-stage sampling design. For cycle 3 of the survey, anthropometric measurements and biological samples were collected in a mobile examination centre (MEC) over 2 years from January 2012 to December 2013. Samples were collected from $\sim 5700$ volunteers aged 3 to 79 years from 16 collection sites stratified in five regions across Canada: Atlantic, Quebec, Ontario, Prairies, and British Columbia. The survey was designed to provide national estimates for children $3-5$ years and for ages $6-11,12-19,20-39,40-59$, and 60-79 years 
for both sexes. Cycle 3 included members of the populations of the 10 provinces. Persons living in the territories, living on reserves and other aboriginal settlements in the provinces, full-time members of the Canadian Forces, the institutionalized, and persons living in certain remote areas were excluded from the survey. Altogether, these exclusions represent $\sim 4 \%$ of the target population. The CHMS cycle 3 was approved by the Health Canada and Public Health Agency of Canada Research Ethics Board. Informed written consent was obtained from all participants older than 14 years of age. Parents or legal guardians provided written consent for younger children and the child gave assent. More detailed information on the aims of the CHMS, target population, and methodologies can be found elsewhere [38].

\subsection{Biochemical Measurements}

Fasted ( $\geq 12 \mathrm{~h}$ ) and nonfasted blood samples were collected and processed in a MEC. Whole blood was collected in $10 \mathrm{~mL} \mathrm{~K} \mathrm{~K}_{2}$ EDTA tubes (CABD366643L, VWR International, Mississauga, ON, Canada). Serum was isolated from blood collected in $4 \mathrm{~mL}$ serum tubes (CABD367812L, VWR International). Whole blood and serum samples were shipped to the Nutrition Laboratory, Health Canada for measurement of $\mathrm{HbA}_{1 \mathrm{c}}$ (whole blood) and serum $\mathrm{Mg}$, albumin, triglyceride, and glucose concentrations using the Vitros 5.1 FS clinical chemistry analyzer (Ortho Clinical Diagnostics, Mississauga, ON, Canada). Serum insulin concentration was measured using the Advia Centaur XP immunoassay analyzer (Siemens Healthcare Diagnostics, Mississauga, ON, Canada). The inter-assay (within lab precision) coefficients of variability (low-high concentration range) for $\mathrm{HbA}_{1 \mathrm{c}}, \mathrm{Mg}$, albumin, triglycerides, glucose and insulin were $1.9 \%-3.1 \%, 1.7 \%-0.9 \%, 1.7 \%-0.9 \%$, $1.4 \%-0.9 \%, 1.5 \%-1.2 \%$, and $5.9 \%-4.8 \%$, respectively. Triglycerides and insulin were only measured in fasted participants. Results from samples with degree of hemolysis exceeding the threshold value for the assay were excluded from the analyses.

\subsection{Collection of Demographic Information}

Information on age, sex, race (i.e., white, South Asian, Chinese, black, Filipino, Latin American, Arab, Southeast Asian, West Asian, Korean, Japanese, other), diabetes, and yearly household income was collected at a household interview with the participants. The interview was conducted by trained interviewers using a computer-assisted interviewing method [38].

\subsection{Calculations}

QUICKI, HOMA-IR, and McAuley's index were calculated using the following equations: QUICKI, $\left(\log \text { insulin }\left(\mu \mathrm{IU} \cdot \mathrm{mL}^{-1}\right)+\log \text { glucose }\left(\mathrm{mg} \cdot \mathrm{dL}^{-1}\right)\right)^{-1}$; HOMA-IR, (glucose $\left(\mathrm{mmol} \cdot \mathrm{L}^{-1}\right.$ ) $\times$ insulin $\left.\left(\mu \mathrm{IU} \cdot \mathrm{mL}^{-1}\right)\right) 22.5^{-1}$; and McAuley's index, $\exp \left(2.63-0.28 \ln\right.$ insulin $\left(\mu \mathrm{IU} \mathrm{mL}{ }^{-1}\right)-0.31 \mathrm{ln}$ triglycerides $\left(\mathrm{mmol} \cdot \mathrm{L}^{-1}\right)$ ). BMI was calculated from weight and height measurements.

\subsection{Statistical Analyses}

The CHMS cycle 3 sampling design yields national estimates when survey weights are applied. Bootstrap weights were used for all variance estimations to account for the complex sampling design [39]. The 16 collection sites from five regional strata restricted the statistical analyses to 11 degrees of freedom. Descriptive statistics are presented as arithmetic means and percentiles with $95 \%$ confidence intervals. A $t$-test or ANOVA followed by Tukey's test was used for pairwise comparison of means. Association of serum Mg concentration with demographic and biochemical characteristics were assessed via linear mixed models. Age, sex, race (white or non-white), diabetes (type 1 and type 2 combined), BMI, and yearly household income were designated as fixed effects. $\mathrm{HbA}_{1 \mathrm{c}}$, QUICKI, HOMA-IR, McAuley's index, and serum albumin, glucose, insulin, and triglyceride concentrations were modeled as random effects to account for the inherent variability associated with these measurements during sampling. Model 1 included the full adult sample set (fasted and nonfasted participants), and associations between $\mathrm{Mg}$ concentrations and age, sex, race, diabetes, BMI, 
household income, albumin, and $\mathrm{HbA}_{1 \mathrm{c}}$ were examined. Two additional models were developed using the fasted subsample. In model 2, associations with glucose, insulin, and triglycerides were investigated in addition to the variables examined in Model 1. In Model 3, associations with the indirect indices of insulin resistance QUICKI, HOMA-IR, and McAuley's index were examined instead of the direct measures glucose, insulin, and triglycerides. The SURVEYREG procedure with backwards elimination was used to develop the final models. For the purpose of interpretation, estimates for the continuous variables were also determined after a transformation using the 5th and 95th percentiles:

$$
Y=(X-5 \text { th percentile of } X) \div(95 \text { th percentile of } X-5 \text { th percentile of } X)
$$

Pregnant women $(n=19)$ and participants with a missing or invalid value were excluded from the analyses. The coefficients of variation for all estimates were $<16.6 \%$ and considered acceptable for unrestricted release based on the CHMS sampling variability guidelines [40]. Statistical significance was set a $p<0.05$. Statistical analyses were performed using SAS/STAT ${ }^{\circledR} 9.3$ software (SAS Institute Inc., Cary, NC, USA).

\section{Results}

Means and percentile distributions for total serum $\mathrm{Mg}$ concentration for 11 sex-age groups between 3 and 79 years are presented in Table 1. Distributions were symmetrical and thus arithmetic means were reported. In general, differences $(p<0.05)$ among sex and age groups were small. For ages 6-11 years, 20-39 years and 40-59 years females had lower means compared to males. Estimations for adolescents and adults at the 10th percentile were below a population-based reference interval for adults of $0.75-0.955 \mathrm{mmol} \cdot \mathrm{L}^{-1}$ [14]. Between $9.5 \%$ and $16.6 \%$ of the adult sex-age groups had a serum $\mathrm{Mg}$ concentration below $0.75 \mathrm{mmol} \cdot \mathrm{L}^{-1}$ (Figure 1). Estimates for the 25 th and 95th percentiles for all sex-age groups were within the reference interval (Table 1). Boxplots show a greater number of older adults of both sexes with serum $\mathrm{Mg}$ concentration below the lower fence (i.e., $1.5 \times$ interquartile range) (Figure S1).

Mean serum Mg concentration between fasted and nonfasted participants were similar $(p \geq 0.05)$ for most sex-age groups (Table S1). However, fasted males and females 6-11 years had lower means than corresponding nonfasted participants. Conversely, fasted females aged 60-79 years had a higher mean compared to non-fasting females of the same age range.

Association of serum $\mathrm{Mg}$ concentration with demographic factors, diabetes and measures of glycemic control and insulin resistance were examined in adults aged 20-79 years using mixed models (data for children and adolescents aged 3-19 years were excluded from these analyses). Serum albumin concentration was included in the models because of a linear relationship with serum $\mathrm{Mg}$ at high and low concentrations [41]. For continuous variables associations were estimated for a defined unit change and after transformation using the 5th and 95th percentiles. After transformation the estimated change in serum $\mathrm{Mg}$ corresponds to the change in the continuous variable from the 5th to the 95th percentile in the population. This is a better indication of the relative strengths of the associations among variables since the magnitudes of associations are compared without confounding by their scales. Estimates of the 5 th and 95th percentiles for each continuous variable are presented for each model.

In Model 1, associations were estimated in fasted and nonfasted adults (Table 2). Being male was associated with higher serum $\mathrm{Mg}$, whereas white race (compared to non-white) or having diabetes (type 1 or type 2) was associated with lower Mg concentrations. Age, household income, and serum albumin concentration were positively associated with serum $\mathrm{Mg}$, while $\mathrm{BMI}$ and $\mathrm{HbA}_{1 \mathrm{c}}$ showed a negative association.

In Models 2 and 3, associations were examined in fasted adults. In Model 2, serum Mg was positively associated with age and household income and negatively associated with diabetes and serum glucose and insulin concentrations (Table 3). In Model 3, age and household income showed positive associations, whereas diabetes and HOMA-IR showed negative associations (Table 4). 
Table 1. Means and distributions of serum magnesium concentrations by sex and age in the Canadian population.

\begin{tabular}{|c|c|c|c|c|c|c|c|c|c|c|c|c|c|c|c|c|c|}
\hline \multirow{3}{*}{$\begin{array}{l}\text { Sex and } \\
\text { Age }\end{array}$} & \multirow{3}{*}{$n$} & \multirow{2}{*}{\multicolumn{2}{|c|}{ Serum Magnesium }} & \multicolumn{14}{|c|}{ Distribution of Serum Magnesium Concentrations } \\
\hline & & & & \multicolumn{2}{|c|}{ 5th } & \multicolumn{2}{|c|}{ 10th } & \multicolumn{2}{|c|}{ 25th } & \multicolumn{2}{|c|}{ 50th } & \multicolumn{2}{|c|}{75 th } & \multicolumn{2}{|c|}{ 90th } & \multicolumn{2}{|c|}{ 95th } \\
\hline & & $\begin{array}{c}\text { Arithmetic } \\
\text { Mean }^{1}\end{array}$ & $95 \%$ CI & Estimate & $95 \% \mathrm{CI}$ & Estimate & $95 \% \mathrm{CI}$ & Estimate & $95 \% \mathrm{CI}$ & Estimate & $95 \% \mathrm{CI}$ & Estimate & $95 \% \mathrm{CI}$ & Estimate & $95 \% \mathrm{CI}$ & Estimate & $95 \% \mathrm{CI}$ \\
\hline & & \multicolumn{16}{|c|}{$\mathrm{mmol} \cdot \mathrm{L}^{-1}$} \\
\hline \multicolumn{18}{|l|}{$\mathrm{All}^{2}$} \\
\hline 3-5 years & 505 & 0.83 & $0.82,0.84$ & 0.74 & $0.72,0.76$ & 0.76 & $0.74,0.77$ & 0.78 & $0.77,0.80$ & 0.82 & $0.80,0.84$ & 0.86 & $0.84,0.88$ & 0.90 & $0.87,0.93$ & 0.92 & $0.90,0.95$ \\
\hline \multicolumn{18}{|l|}{ Male $^{3}$} \\
\hline 6-11 years & 493 & $0.83^{a, *}$ & $0.82,0.84$ & 0.73 & $0.71,0.76$ & 0.76 & $0.73,0.78$ & 0.79 & $0.78,0.81$ & 0.83 & $0.82,0.84$ & 0.86 & $0.85,0.88$ & 0.88 & $0.86,0.91$ & 0.91 & $0.88,0.94$ \\
\hline $12-19$ years & 490 & $0.80^{\mathrm{c}}$ & $0.78,0.81$ & 0.71 & $0.68,0.74$ & 0.73 & $0.70,0.75$ & 0.76 & $0.72,0.79$ & 0.79 & $0.77,0.81$ & 0.83 & $0.80,0.85$ & 0.87 & $0.84,0.89$ & 0.88 & $0.87,0.90$ \\
\hline $20-39$ years & 510 & $0.81^{b, c, *}$ & $0.80,0.82$ & 0.69 & $0.64,0.74$ & 0.73 & $0.70,0.76$ & 0.77 & $0.74,0.79$ & 0.80 & $0.79,0.82$ & 0.84 & $0.83,0.86$ & 0.87 & $0.86,0.89$ & 0.90 & $0.87,0.92$ \\
\hline $40-59$ years & 538 & $0.82^{a, b, *}$ & $0.81,0.83$ & 0.71 & $0.68,0.73$ & 0.74 & $0.71,0.77$ & 0.78 & $0.76,0.80$ & 0.82 & $0.80,0.84$ & 0.86 & $0.84,0.88$ & 0.90 & $0.88,0.92$ & 0.91 & $0.88,0.94$ \\
\hline $60-79$ years & 509 & $0.81^{\mathrm{b}}$ & $0.81,0.82$ & 0.69 & $0.67,0.71$ & 0.72 & $0.71,0.74$ & 0.77 & $0.75,0.79$ & 0.82 & $0.80,0.84$ & 0.86 & $0.84,0.87$ & 0.89 & $0.88,0.91$ & 0.91 & $0.89,0.93$ \\
\hline \multicolumn{18}{|l|}{ Female $^{3}$} \\
\hline 6-11 years & 455 & $0.82^{a}$ & $0.81,0.83$ & 0.74 & $0.72,0.76$ & 0.75 & $0.73,0.78$ & 0.78 & $0.77,0.80$ & 0.82 & $0.80,0.84$ & 0.85 & $0.83,0.86$ & 0.88 & $0.86,0.89$ & 0.89 & $0.88,0.90$ \\
\hline $12-19$ years & 486 & $0.79^{\mathrm{d}}$ & $0.78,0.80$ & 0.70 & $0.68,0.72$ & 0.72 & $0.70,0.73$ & 0.75 & $0.73,0.77$ & 0.78 & $0.77,0.80$ & 0.82 & $0.80,0.83$ & 0.86 & $0.84,0.87$ & 0.88 & $0.86,0.90$ \\
\hline 20-39 years & 511 & $0.80^{c, d}$ & $0.79,0.80$ & 0.71 & $0.70,0.72$ & 0.73 & $0.71,0.75$ & 0.76 & $0.74,0.78$ & 0.79 & $0.77,0.80$ & 0.82 & $0.80,0.84$ & 0.85 & $0.82,0.88$ & 0.87 & $0.85,0.89$ \\
\hline $40-59$ years & 532 & $0.81^{b, c}$ & $0.80,0.82$ & 0.69 & $0.64,0.74$ & 0.72 & $0.69,0.76$ & 0.76 & $0.74,0.78$ & 0.81 & $0.79,0.82$ & 0.85 & $0.83,0.87$ & 0.88 & $0.86,0.89$ & 0.89 & $0.87,0.92$ \\
\hline $60-79$ years & 532 & $0.82^{a, b}$ & $0.81,0.83$ & 0.67 & $0.65,0.69$ & 0.71 & $0.69,0.73$ & 0.77 & $0.75,0.79$ & 0.82 & $0.80,0.83$ & 0.86 & $0.84,0.88$ & 0.90 & $0.88,0.92$ & 0.93 & $0.90,0.97$ \\
\hline
\end{tabular}

${ }^{1}$ Values in a column and within a sex group without a common superscript letter differ, $p<0.05 .{ }^{*}$ Different compared to females in the same age group, $p<0.05 ;{ }^{2}$ Includes nonfasted males and females; ${ }^{3}$ Includes fasted and nonfasted participants. 
Table 2. Association of serum $\mathrm{Mg}$ with demographic factors, diabetes and biochemical measures ${ }^{1}$.

\begin{tabular}{|c|c|c|c|c|c|}
\hline \multirow{2}{*}{ IV } & Estimate $(95 \% \mathrm{CI})^{2,3}$ & Estimate $(95 \% \mathrm{CI})^{3,4}$ & \multirow{2}{*}{$p$} & \multicolumn{2}{|c|}{ Distribution of Continuous IV } \\
\hline & \multicolumn{2}{|c|}{$\mathrm{mmol} \cdot \mathrm{L}^{-1}$} & & 5 th $(95 \%$ CI $)$ & 95th (95\% CI) \\
\hline Male $^{5}$ & $0.01(0.00,0.01)$ & - & $<0.01$ & - & - \\
\hline White race 6 & $-0.01(-0.02,-0.00)$ & - & $<0.001$ & - & - \\
\hline Diabetes 7 & $-0.04(-0.05,-0.02)$ & - & $<0.001$ & - & - \\
\hline Age, year & $0.01(0.01,0.01)$ & $0.05(0.04,0.05)$ & $<0.001$ & $21.1(18.3,23.9)$ & $71.7(70.1,73.3)$ \\
\hline BMI, $\mathrm{kg} \cdot \mathrm{m}^{-2}$ & $-0.002(-0.002,-0.001)$ & $-0.03(-0.03,-0.02)$ & $<0.001$ & $19.7(19.1,20.3)$ & $36.3(34.7,38.0)$ \\
\hline Household income, $\mathrm{K}$ & $0.0005(0.0001,0.0008)$ & $0.01(0.00,0.01)$ & $<0.01$ & $15.0(11.5,18.5)$ & $196.7(166.2,227.2)$ \\
\hline Serum albumin, $g \cdot L^{-1}$ & $0.002(0.001,0.003)$ & $0.02(0.01,0.03)$ & $<0.001$ & $37.8(36.3,39.3)$ & $48.9(47.4,50.5)$ \\
\hline $\mathrm{HbA}_{1 \mathrm{c}}, \%$ & $-0.01(-0.02,-0.01)$ & $-0.02(-0.03,-0.02)$ & $<0.001$ & $4.8(4.6,5.0)$ & $6.5(6.1,6.9)$ \\
\hline
\end{tabular}

${ }^{1}$ Results from fasted and nonfasted adults aged 20-79 years, $n=2838$ (Model 1). Sex, race, diabetes, age, BMI, household income, serum albumin concentration and HbA $\mathrm{A}_{1 \mathrm{c}}$ were tested in the model. All variables were statistically significant $(p<0.05)$ and retained in the final model. $\mathrm{HbA}_{1 c}$, glycated hemoglobin; IV, independent variables; $\mathrm{Mg}$, magnesium; ${ }^{2} \mathrm{Changes}$ in serum $\mathrm{Mg}$ concentrations associated with being male (compared to female), white race (compared to non-white race), diabetes, a 10 years increment in age, a $1 \mathrm{~kg} \cdot \mathrm{m}^{-2}$ increment in BMI, a $\$ 10 \mathrm{~K}$ increment in yearly household income, a $1 \mathrm{~g} \cdot \mathrm{L}^{-1}$ increment in serum albumin concentration and a $1 \%$ increment in $\mathrm{HbA} \mathrm{Ac}_{1}{ }^{3}$ Estimates are adjusted for all IV in the model; ${ }^{4}$ Continuous variables were transformed using the 5 th and 95 th percentiles prior to analysis; ${ }^{5}$ Males, $n=1438 ;{ }^{6}$ Whites, $n=2331 ;{ }^{7}$ Diabetics, $n=217$.

Table 3. Association of serum $\mathrm{Mg}$ with demographic factors, diabetes and serum glucose and insulin concentrations ${ }^{1}$.

\begin{tabular}{|c|c|c|c|c|c|}
\hline \multirow{2}{*}{ IV } & Estimate $(95 \% \mathrm{CI})^{2,3}$ & Estimate $(95 \% \mathrm{CI})^{3,4}$ & \multirow{2}{*}{$p$} & \multicolumn{2}{|c|}{ Distribution of Continuous IV } \\
\hline & $\mathrm{mmol} \cdot \mathrm{L}^{-}$ & & & 5 th $(95 \%$ CI $)$ & 95th (95\% CI) \\
\hline Diabetes 5 & $-0.06(-0.07,-0.04)$ & - & $<0.001$ & - & - \\
\hline Age, year & $0.01(0.01,0.01)$ & $0.04(0.03,0.05)$ & $<0.001$ & $20.6(17.9,23.3)$ & $70.8(69.1,72.4)$ \\
\hline Household income, $\mathrm{K}$ & $0.0008(0.0004,0.0012)$ & $0.02(0.01,0.02)$ & $<0.001$ & $14.5(10.3,18.7)$ & $199.0(162.5,235.6)$ \\
\hline Serum glucose, $\mathrm{mmol} \cdot \mathrm{L}^{-1}$ & $-0.01(-0.01,-0.00)$ & $-0.01(-0.02,-0.01)$ & $<0.001$ & $4.3(4.1,4.4)$ & $6.6(5.9,7.4)$ \\
\hline Serum insulin, $\mathrm{pmol} \cdot \mathrm{L}^{-1}$ & $-0.00008(-0.00013,-0.00004)$ & $-0.01(-0.02,-0.00)$ & $<0.001$ & $25.1(21.9,28.2)$ & $180.1(156.7,203.4)$ \\
\hline
\end{tabular}

${ }^{1}$ Results from fasted adults aged 20-79 years, $n=1621$ (Model 2). Sex, race, diabetes, age, BMI, household income, serum albumin concentration, HbA 1 , serum glucose concentration, werds elimination and IV in $L^{-1}$ intion model $;{ }^{4}$ Continuous variables were transformed using the 5 th and 95 th percentiles prior to analysis; ${ }^{5}$ Diabetics, $n=99$. 
Table 4. Association of serum $\mathrm{Mg}$ with demographic factors, diabetes and HOMA-IR ${ }^{1}$.

\begin{tabular}{|c|c|c|c|c|c|}
\hline \multirow{2}{*}{ IV } & Estimate $(95 \% \mathrm{CI})^{2,3}$ & Estimate $(95 \% \mathrm{CI})^{3,4}$ & \multirow{2}{*}{$p$} & \multicolumn{2}{|c|}{ Distribution of Continuous IV } \\
\hline & \multicolumn{2}{|c|}{$\mathrm{mmol} \cdot \mathrm{L}^{-1}$} & & 5 th $(95 \%$ CI $)$ & 95th $(95 \%$ CI ) \\
\hline Diabetes 5 & $-0.07(-0.08,-0.06)$ & - & $<0.001$ & - & - \\
\hline Age, year & $0.01(0.01,0.01)$ & $0.04(0.03,0.05)$ & $<0.001$ & $20.6(18.0,23.3)$ & $70.8(69.1,72.5)$ \\
\hline Household income, $\mathrm{K}$ & $0.0008(0.0004,0.0012)$ & $0.02(0.01,0.02)$ & $<0.001$ & $14.5(10.3,18.7)$ & $199.0(162.0,236.0)$ \\
\hline HOMA-IR & $-0.003(-0.004,-0.002)$ & $-0.02(-0.02,-0.01)$ & $<0.001$ & $0.80(0.67,0.93)$ & $6.99(6.34,7.65)$ \\
\hline
\end{tabular}

${ }^{1}$ Results from fasted adults aged 20-79 years, $n=1621$ (Model 3). Sex, race, diabetes, age, BMI, household income, serum albumin concentration, HbA $\mathrm{Ac}_{1 \mathrm{c}}$ serum triglyceride concentration and HOMA-IR were tested in the model. Statistically significant $(p<0.05)$ variables were selected by backwards elimination and retained in the final model. HOMA-IR, homeostatic model assessment of insulin resistance; IV, independent variables; $\mathrm{Mg}$, magnesium; ${ }^{2}$ Changes in serum $\mathrm{Mg}$ concentrations associated with diabetes, a 10 years increment in age, a $\$ 10 \mathrm{~K}$ increment in yearly household income and an increment of 1 for HOMA-IR; ${ }^{3}$ Estimates are adjusted for all IV in the model; ${ }^{4}$ Continuous variables were transformed using the 5th and 95th percentiles prior to analysis; ${ }^{5}$ Diabetics, $n=99$. 


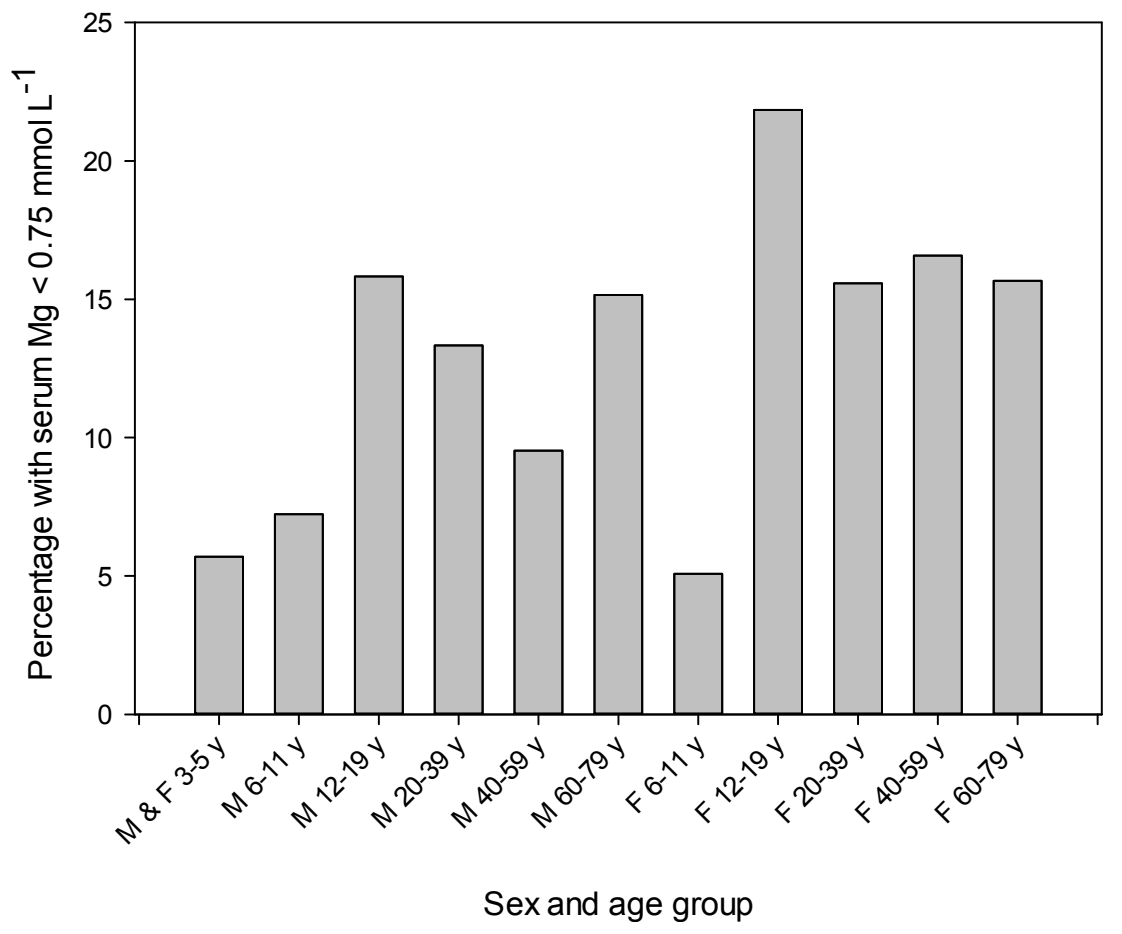

Figure 1. Percentage of each sex and age group with a serum $\mathrm{Mg}$ concentration below $0.75 \mathrm{mmol} \cdot \mathrm{L}^{-1}$. The total number of participants $(n)$ examined for each sex-age group is shown in Table 1. F, females; $\mathrm{M}$, males; $\mathrm{y}$, years.

\section{Discussion}

This study describes current (2012-2013) estimates of serum Mg concentrations in a nationally representative sample of the Canadian population for ages 3-79 years. These results are the first national estimates in Canada or the United States since the NHANES I conducted between 1971 and 1973 [14]. Results from that study showed a normal distribution for serum Mg concentration, with 95\% of adults aged $18-74$ years having a value between 0.75 and $0.955 \mathrm{mmol} \cdot \mathrm{L}^{-1}$. Those estimates were considered as normative for the United States population and were used to establish a population-based reference interval. Serum Mg concentrations in the present study were also normally distributed. Substantial proportions of the adult sex-age groups $(9.5 \%-16.6 \%)$ and adolescents aged $12-19$ years (15.8\%-21.8\%) had a serum $\mathrm{Mg}$ concentration below $0.75 \mathrm{mmol} \cdot \mathrm{L}^{-1}$, the lower cut-off of the reference interval. All estimates at the 10th percentile for adolescents and adults were also below $0.75 \mathrm{mmol} \cdot \mathrm{L}^{-1}$. In addition, means in this study were lower than means reported in the NHANES I for comparable sex-age groups [14]. Collectively, these results suggest that present-day serum $\mathrm{Mg}$ concentrations in Canada are lower compared to concentrations in the United States population in the early 1970s. Since it has been suggested that a serum $\mathrm{Mg}$ concentration below $0.75 \mathrm{mmol} \cdot \mathrm{L}^{-1}$ represents relatively severe $\mathrm{Mg}$ deficiency [11], these results raise suspicions of $\mathrm{Mg}$ deficiency in the Canadian population. Estimates at the 95th percentile for all sex-age groups were within the reference interval indicating the rarity of hypermagnesaemia in the population.

Similar to results from the NHANES I, only small differences in serum Mg concentrations were found among sex and age groups. Serum Mg concentrations were highest for children and showed a small increase with age from adolescents 12-19 years to older adults 60-79 years. Among demographic factors, age was the strongest predictor of serum $\mathrm{Mg}$ concentration in adults. The magnitudes of associations with sex, race, and household income were considerably smaller. A major finding from the NHANES I was the lower serum Mg in black Americans compared to white Americans [14]. In the present study, being white was associated with a lower serum Mg concentration 
than being non-white. It should be mentioned that because of the small sample sizes for all racial groups other than whites (including blacks), comparison among races in this study was restricted to the general groups of whites and non-whites.

Boxplot analyses revealed a greater number of older adults with serum Mg values below the lower fence (outliers) indicating that older adults are more prone to marked hypomagnesaemia. Possible explanations include lower dietary $\mathrm{Mg}$ intakes, reduced gastrointestinal $\mathrm{Mg}$ absorption, and increased renal $\mathrm{Mg}$ excretion in the elderly [42]. The higher occurrence of health conditions (e.g., diabetes) and other factors (e.g., use of hypermagnesuric diuretics) that alter Mg metabolism may also contribute [43].

Serum $\mathrm{Mg}$ concentrations were compared between fasted and nonfasted participants. Mean serum Mg concentrations were found to be lower for fasted children aged 6-11 years, but higher for fasted females aged 60-79 years. It is presently unclear what accounts for these differences. While the differences could be considered modest, these data offer a caution when interpreting results from a routine serum $\mathrm{Mg}$ test for these sex-age groups.

Inverse associations between serum $\mathrm{Mg}$ and diabetes and comorbidities such as poor glycemic control and insulin resistance have been well established. However, it is likely that these relationships are affected by factors that can differ among countries or change in populations over time (e.g., dietary Mg intakes, supplement and medication use). Thus, in this study associations of serum $\mathrm{Mg}$ concentration with diabetes and measures of glycemic regulation and insulin resistance were investigated in adults to determine the magnitude of these associations in a relatively current nationally-representative dataset. Diabetes was a strong predictor of serum $\mathrm{Mg}$ concentration. The estimated lower serum $\mathrm{Mg}$ in diabetics (ranging from -0.04 to $-0.07 \mathrm{mmol} \cdot \mathrm{L}^{-1}$ in the various models) accounts for $\sim 20 \%$ to $34 \%$ of the spread between the lower and upper limits of the normal reference interval. These estimates are substantial and likely have clinical relevance. Serum $\mathrm{Mg}$ was also negatively associated with $\mathrm{HbA}_{1 \mathrm{c}}$ and fasting serum glucose concentration. A negative effect of diabetes on $\mathrm{Mg}$ status is noteworthy given the high prevalence of diabetes in Canada which is expected to rise to over $10 \%$ by the year 2020 [37].

The hyperinsulinemic euglycemic clamp is considered the "gold standard" for assessment of insulin sensitivity, but the complexity of the method limits its use in large studies [44]. In this study, associations between serum $\mathrm{Mg}$ and more practical surrogate indices of insulin resistance [45] were examined. Fasting insulin concentration correlates strongly with insulin resistance [46] and HOMA-IR is considered a robust tool for the evaluation of insulin resistance in large epidemiological studies [47,48]. Serum $\mathrm{Mg}$ showed a negative association with both fasting insulin and HOMA-IR, indicating a positive relationship between serum $\mathrm{Mg}$ and insulin sensitivity. Notably, these relationships were observed in models controlling for diabetes. It should be mentioned that HOMA-IR was determined to be a better predictor of serum $\mathrm{Mg}$ concentration compared to other proxy measures of insulin resistance such as QUICKI or McAuley's index that were insignificant $(p \geq 0.05)$ in our selection process.

There is evidence indicating that the relationship between Mg deficiency and type 2 diabetes is bidirectional. $\mathrm{Mg}$ deficiency is a common manifestation in type 1 and type 2 diabetics $[26,27]$ and may also increase the risk of diabetes and its complications [29-31]. The negative associations between serum $\mathrm{Mg}$ and measures of glycemic regulation observed in this study are in agreement with studies indicating that poor glycemic control lowers serum $\mathrm{Mg}$ concentrations [33,34]. However, lower serum $\mathrm{Mg}$ may also contribute to poorer glycemic regulation and insulin sensitivity. Studies indicate that $\mathrm{Mg}$ supplementation improves glucose and insulin sensitivity parameters [49,50]. A meta-analysis of randomized controlled trials showed that $\mathrm{Mg}$ supplementation for over four months improved fasting glucose and HOMA-IR in diabetic and non-diabetic subjects [49]. In another meta-analysis, $\mathrm{Mg}$ supplementation was shown to reduce fasting plasma glucose in diabetics and improve HOMA-IR and plasma glucose (in a $2 \mathrm{~h}$ oral glucose tolerance test) in persons at high risk of diabetes [50]. The mechanisms by which Mg deficiency may increase diabetes risk are poorly understood but may 
involve increased oxidative stress and inflammation [35,51,52]. It is important to mention that this study does not provide any information on the temporality of the reported associations with serum $\mathrm{Mg}$ given the cross-sectional design.

The main strength of this study is the CHMS cycle 3 study design, including the large sample size that is representative of the Canadian population that is ideal for estimating national serum $\mathrm{Mg}$ concentrations and population distributions. The use of mixed models and continuous variables (rather than dichotomizing continuous variables) is also a strength. Limitations include the absence of $\mathrm{Mg}$ intake data (including supplement use) for comparison with serum $\mathrm{Mg}$ concentrations. The different methodologies used to measure serum Mg in this study and the NHANES I (colorimetric vs. atomic absorption spectroscopy) limits, to some extent, the comparison of results between studies; however, serum Mg measurements by the colorimetric method (the most commonly used method) or atomic absorption show excellent agreement $(R>0.99)$ [53]. Also, based on the responses to the household questionnaire, many diabetics in this study could not be categorized as having type 1 or type 2 diabetes. Thus, in our analyses, diabetics included participants with type 1 or type 2 diabetes or both.

The limitations of total serum $\mathrm{Mg}$ concentration as a biomarker of $\mathrm{Mg}$ status also merit discussion. Only a small fraction $(\sim 0.3 \%)$ of total body $\mathrm{Mg}$ is present in the serum and fluctuations in serum proteins such as albumin can alter Mg concentrations [41]. Furthermore, serum Mg may not always accurately reflect intracellular $\mathrm{Mg}$ deficiency. Serum $\mathrm{Mg}$ concentration is tightly regulated primarily at the level of renal excretion. Bone also maintains circulating concentrations by acting as a store for $\mathrm{Mg}$ and supplementing the serum under conditions of deficiency. This homeostatic regulation is likely a major factor accounting for the poor association observed between serum $\mathrm{Mg}$ concentrations and dietary $\mathrm{Mg}$ intakes, particularly when intakes meet nutrient requirements [54,55]. Despite these limitations, low serum $\mathrm{Mg}$ is usually indicative of $\mathrm{Mg}$ deficiency. Serum $\mathrm{Mg}$ is decreased in a dose-dependent manner in animal models of dietary Mg deficiency, demonstrating that low Mg intakes (Mg deficiency) reduce serum $\mathrm{Mg}$ concentration [56,57]. Human studies have shown that serum $\mathrm{Mg}$ is responsive to long-term changes in dietary $\mathrm{Mg}$ intakes [58] and increases with $\mathrm{Mg}$ supplementation $[13,59,60]$. A meta-analysis of randomized controlled trials showed that serum $\mathrm{Mg}$ concentrations increase in a dose- and time-dependent manner with oral $\mathrm{Mg}$ supplementation, and the response is greater when baseline circulating Mg concentrations are lower, suggesting that serum Mg provides useful information about underlying $\mathrm{Mg}$ status [13]. It has been suggested that a serum $\mathrm{Mg}$ value below $0.75 \mathrm{mmol} \cdot \mathrm{L}^{-1}$ is a useful measure of relatively severe $\mathrm{Mg}$ deficiency, but $\mathrm{Mg}$ deficiency cannot be excluded for persons with a value between 0.75 and $0.85 \mathrm{mmol} \cdot \mathrm{L}^{-1}[11,12]$.

\section{Conclusions}

This study reports serum $\mathrm{Mg}$ concentrations for 11 sex-age groups between 3 and 79 years in the Canadian population. Between $9.5 \%$ and $16.6 \%$ of the adult sex-age groups were hypomagnesaemic (serum $\mathrm{Mg}<0.75 \mathrm{mmol} \cdot \mathrm{L}^{-1}$ ) in relation to a population-based reference interval [14]. There is a need to establish an evidence-based reference interval (or at minimum a lower cut-off value) for health that will allow more accurate assessment of the prevalence of $\mathrm{Mg}$ deficiency in Canada and related health risk based on results from this study [61]. Among demographic factors, age was the strongest predictor of serum Mg concentration. Serum Mg concentration was negatively associated with diabetes, BMI, serum glucose, serum insulin, $\mathrm{HbA}_{1 \mathrm{c}}$, and HOMA-IR. These results are consistent with a growing body of evidence indicating a negative effect of diabetes, poor glycemic control, and insulin resistance on Mg status.

Supplementary Materials: The following are available online at http:/ /www.mdpi.com/2072-6643/9/3/296/s1, Figure S1: Boxplots of serum Mg concentrations by sex-age group, Table S1: Means and distributions of serum magnesium concentrations by sex and age in fasted and nonfasted Canadians.

Acknowledgments: This research was funded by the Bureau of Nutritional Sciences and the Bureau of Food Surveillance and Science Integration, Health Canada. 
Author Contributions: J.B. conceived the study; J.B., K.C.W. and S.H. analyzed the data; J.B. wrote the paper.

Conflicts of Interest: The authors declare no conflict of interest.

\section{References}

1. Swaminathan, R. Magnesium metabolism and its disorders. Clin. Biochem. Rev. 2003, 24, 47-66. [PubMed]

2. Volpe, S.L. Magnesium in disease prevention and overall health. Adv. Nutr. 2013, 4, 378S-383S. [CrossRef] [PubMed]

3. Elin, R.J. Magnesium: The fifth but forgotten electrolyte. Am. J. Clin. Pathol. 1994, 102, 616-622. [CrossRef] [PubMed]

4. Wolf, F.I.; Cittadini, A. Magnesium in cell proliferation and differentiation. Front. Biosci. 1999, 4, D607-D617. [CrossRef] [PubMed]

5. Moshfegh, A.; Goldman, J.D.; Ahuja, J.; Rhodes, D.; LaComb, R. What We Eat in America, NHANES 2005-2006: Usual Nutrient Intakes from Food and Water Compared to 1997 Dietary Reference Intakes for Vitamin D, Calcium, Phosphorus, and Magnesium; U.S. Department of Agriculture, Agriculture Research Service: Washington, DC, USA, 2009.

6. Health Canada. Do Canadian Adults Meet Their Nutrient Requirements through Food Intake Alone? Available online: http://www.hc-sc.gc.ca/fn-an/surveill/nutrition/commun/art-nutr-adult-eng.php (accessed on 23 February 2017).

7. Ford, E.S.; Mokdad, A.H. Dietary magnesium intake in a national sample of US adults. J. Nutr. 2003, 133, 2879-2882. [PubMed]

8. Food and Nutrition Board, Institute of Medicine. Dietary Reference Intakes for Calcium, Phosphorus, Magnesium, Vitamin D, and Fluoride; National Academy Press: Washington, DC, USA, 1997; pp. 190-249.

9. EFSA Panel on Dietetic Products, Nutrition and Allergies (NDA). Scientific opinion on dietary reference values for magnesium. EFSA J. 2015, 13, 4186.

10. Joint FAO/WHO Expert Consultation. Vitamin and Mineral Requirements in Human Nutrition: Report of a Joint FAO/WHO Expert Consultation, 2nd ed.; World Health Organization: Geneva, Switzerland, 2004.

11. Arnaud, M.J. Update on the assessment of magnesium status. Br. J. Nutr. 2008, 99, S24-S36. [CrossRef] [PubMed]

12. Elin, R.J. Assessment of magnesium status for diagnosis and therapy. Magnes. Res. 2010, 23, S194-S198. [PubMed]

13. Zhang, X.; Del Gobbo, L.C.; Hruby, A.; Rosanoff, A.; He, K.; Dai, Q.; Costello, R.B.; Zhang, W.; Song, Y. The circulating concentration and 24-h urine excretion of magnesium dose- and time-dependently respond to oral magnesium supplementation in a meta-analysis of randomized controlled trials. J. Nutr. 2016, 146, 595-602. [CrossRef] [PubMed]

14. Lowenstein, F.W.; Stanton, M.F. Serum magnesium levels in the United States, 1971-1974. J. Am. Coll. Nutr. 1986, 5, 399-414. [CrossRef] [PubMed]

15. Ma, J.; Folsom, A.R.; Melnick, S.L.; Eckfeldt, J.H.; Sharrett, A.R.; Nabulsi, A.A.; Hutchinson, R.G.; Metcalf, P.A. Associations of serum and dietary magnesium with cardiovascular disease, hypertension, diabetes, insulin, and carotid arterial wall thickness: The ARIC study. Atherosclerosis Risk in Communities Study. J. Clin. Epidemiol. 1995, 48, 927-940. [CrossRef]

16. Zhang, X.; Li, Y.; Del Gobbo, L.C.; Rosanoff, A.; Wang, J.; Zhang, W.; Song, Y. Effects of magnesium supplementation on blood pressure: A meta-analysis of randomized double-blind placebo-controlled trials. Hypertension 2016, 68, 324-333. [CrossRef] [PubMed]

17. Kieboom, B.C.; Niemeijer, M.N.; Leening, M.J.; van den Berg, M.E.; Franco, O.H.; Deckers, J.W.; Hofman, A.; Zietse, R.; Stricker, B.H.; Hoorn, E.J. Serum magnesium and the risk of death from coronary heart disease and sudden cardiac death. J. Am. Heart Assoc. 2016, 5, e002707. [CrossRef] [PubMed]

18. Peacock, J.M.; Ohira, T.; Post, W.; Sotoodehnia, N.; Rosamond, W.; Folsom, A.R. Serum magnesium and risk of sudden cardiac death in the Atherosclerosis Risk in Communities (ARIC) Study. Am. Heart J. 2010, 160, 464-470. [CrossRef] [PubMed]

19. Orchard, T.S.; Larson, J.C.; Alghothani, N.; Bout-Tabaku, S.; Cauley, J.A.; Chen, Z.; LaCroix, A.Z.; Wactawski-Wende, J.; Jackson, R.D. Magnesium intake, bone mineral density, and fractures: Results from the Women's Health Initiative Observational study. Am. J. Clin. Nutr. 2014, 99, 926-933. [CrossRef] [PubMed] 
20. Del Gobbo, L.C.; Imamura, F.; Wu, J.H.; de Oliveira Otto, M.C.; Chiuve, S.E.; Mozaffarian, D. Circulating and dietary magnesium and risk of cardiovascular disease: A systematic review and meta-analysis of prospective studies. Am. J. Clin. Nutr. 2013, 98, 160-173. [CrossRef] [PubMed]

21. Qu, X.; Jin, F.; Hao, Y.; Li, H.; Tang, T.; Wang, H.; Yan, W.; Dai, K. Magnesium and the risk of cardiovascular events: A meta-analysis of prospective cohort studies. PLoS ONE 2013, 8, e57720. [CrossRef] [PubMed]

22. Chen, G.C.; Pang, Z.; Liu, Q.F. Magnesium intake and risk of colorectal cancer: A meta-analysis of prospective studies. Eur. J. Clin. Nutr. 2012, 66, 1182-1186. [CrossRef] [PubMed]

23. Qu, X.; Jin, F.; Hao, Y.; Zhu, Z.; Li, H.; Tang, T.; Dai, K. Nonlinear association between magnesium intake and the risk of colorectal cancer. Eur. J. Gastroenterol. Hepatol. 2013, 25, 309-318. [CrossRef] [PubMed]

24. Bertinato, J.; Lavergne, C.; Rahimi, S.; Rachid, H.; Vu, N.A.; Plouffe, L.J.; Swist, E. Moderately low magnesium intake impairs growth of lean body mass in obese-prone and obese-resistant rats fed a high-energy diet. Nutrients 2016, 8, 253. [CrossRef] [PubMed]

25. Veronese, N.; Berton, L.; Carraro, S.; Bolzetta, F.; De Rui, M.; Perissinotto, E.; Toffanello, E.D.; Bano, G.; Pizzato, S.; Miotto, F.; et al. Effect of oral magnesium supplementation on physical performance in healthy elderly women involved in a weekly exercise program: A randomized controlled trial. Am. J. Clin. Nutr. 2014, 100, 974-981. [CrossRef] [PubMed]

26. De Valk, H.W. Magnesium in diabetes mellitus. Neth. J. Med. 1999, 54, 139-146. [CrossRef]

27. Pham, P.C.; Pham, P.M.; Pham, S.V.; Miller, J.M.; Pham, P.T. Hypomagnesemia in patients with type 2 diabetes. Clin. J. Am. Soc. Nephrol. 2007, 2, 366-373. [CrossRef] [PubMed]

28. Kao, W.H.; Folsom, A.R.; Nieto, F.J.; Mo, J.P.; Watson, R.L.; Brancati, F.L. Serum and dietary magnesium and the risk for type 2 diabetes mellitus: The Atherosclerosis Risk in Communities Study. Arch. Intern. Med. 1999, 159, 2151-2159. [CrossRef] [PubMed]

29. Larsson, S.C.; Wolk, A. Magnesium intake and risk of type 2 diabetes: A meta-analysis. J. Intern. Med. 2007, 262, 208-214. [CrossRef] [PubMed]

30. Weng, L.C.; Lee, N.J.; Yeh, W.T.; Ho, L.T.; Pan, W.H. Lower intake of magnesium and dietary fiber increases the incidence of type 2 diabetes in Taiwanese. J. Formos. Med. Assoc. 2012, 111, 651-659. [CrossRef] [PubMed]

31. Gommers, L.M.; Hoenderop, J.G.; Bindels, R.J.; de Baaij, J.H. Hypomagnesemia in type 2 diabetes: A vicious circle? Diabetes 2016, 65, 3-13. [CrossRef] [PubMed]

32. Bertinato, J.; Xiao, C.W.; Ratnayake, W.M.; Fernandez, L.; Lavergne, C.; Wood, C.; Swist, E. Lower serum magnesium concentration is associated with diabetes, insulin resistance, and obesity in South Asian and white Canadian women but not men. Food Nutr. Res. 2015, 59, 25974. [CrossRef] [PubMed]

33. Arpaci, D.; Tocoglu, A.G.; Ergenc, H.; Korkmaz, S.; Ucar, A.; Tamer, A. Associations of serum magnesium levels with diabetes mellitus and diabetic complications. Hippokratia 2015, 19, 153-157. [PubMed]

34. Sinha, S.; Sen, S. Status of zinc and magnesium levels in type 2 diabetes mellitus and its relationship with glycemic status. Int. J. Diabetes Dev. Ctries. 2014, 34, 220-223. [CrossRef]

35. Kim, D.J.; Xun, P.; Liu, K.; Loria, C.; Yokota, K.; Jacobs, D.R., Jr.; He, K. Magnesium intake in relation to systemic inflammation, insulin resistance, and the incidence of diabetes. Diabetes Care 2010, 33, 2604-2610. [CrossRef] [PubMed]

36. Shields, M.; Carroll, M.D.; Ogden, C.L. Adult obesity prevalence in Canada and the United States. NCHS Data Brief 2011, 56, 1-8.

37. Public Health Agency of Canada. Diabetes in Canada: Facts and Figures from a Public Health Perspective. Available online: http:/ / www.phac-aspc.gc.ca/cd-mc/publications/diabetes-diabete/facts-figures-faitschiffres-2011/index-eng.php (accessed on 23 February 2017).

38. Statistics Canada. Canadian Health Measures Survey (CHMS). Available online: http://www23.statcan.gc. $\mathrm{ca} / \mathrm{imdb} / \mathrm{p} 2 \mathrm{SV} . \mathrm{pl}$ ? Function=getSurvey\&Id=136652 (accessed on 23 February 2017).

39. Giroux, S. Canadian Health Measures Survey: Sampling strategy overview. Health Rep. 2007, 18, S31-S36.

40. Statistics Canada. Canadian Health Measures Survey (CHMS) Data User Guide: Cycle 1. Available online: http://www23.statcan.gc.ca/imdb-bmdi/document/5071_D2_T1_V1-eng.htm (accessed on 23 February 2017).

41. Kroll, M.H.; Elin, R.J. Relationships between magnesium and protein concentrations in serum. Clin. Chem. 1985, 31, 244-246. [PubMed]

42. Seelig, M.S.; Preuss, H.G. Magnesium metabolism and perturbations in the elderly. Geriatr. Nephrol. Urol. 1994, 4, 101-111. [CrossRef] 
43. Barbagallo, M.; Belvedere, M.; Dominguez, L.J. Magnesium homeostasis and aging. Magnes. Res. 2009, 22, 235-246. [PubMed]

44. DeFronzo, R.A.; Tobin, J.D.; Andres, R. Glucose clamp technique: A method for quantifying insulin secretion and resistance. Am. J. Physiol. 1979, 237, E214-E223. [PubMed]

45. Singh, B.; Saxena, A. Surrogate markers of insulin resistance: A review. World J. Diabetes 2010, 1, 36-47. [CrossRef] [PubMed]

46. Olefsky, J.; Farquhar, J.W.; Reaven, G. Relationship between fasting plasma insulin level and resistance to insulin-mediated glucose uptake in normal and diabetic subjects. Diabetes 1973, 22, 507-513. [CrossRef] [PubMed]

47. Matthews, D.R.; Hosker, J.P.; Rudenski, A.S.; Naylor, B.A.; Treacher, D.F.; Turner, R.C. Homeostasis model assessment: Insulin resistance and beta-cell function from fasting plasma glucose and insulin concentrations in man. Diabetologia 1985, 28, 412-419. [CrossRef] [PubMed]

48. Gutch, M.; Kumar, S.; Razi, S.M.; Gupta, K.K.; Gupta, A. Assessment of insulin sensitivity/resistance. Indian J. Endocrinol. Metab. 2015, 19, 160-164. [CrossRef] [PubMed]

49. Simental-Mendia, L.E.; Sahebkar, A.; Rodriguez-Moran, M.; Guerrero-Romero, F. A systematic review and meta-analysis of randomized controlled trials on the effects of magnesium supplementation on insulin sensitivity and glucose control. Pharmacol. Res. 2016, 111, 272-282. [CrossRef] [PubMed]

50. Veronese, N.; Watutantrige-Fernando, S.; Luchini, C.; Solmi, M.; Sartore, G.; Sergi, G.; Manzato, E.; Barbagallo, M.; Maggi, S.; Stubbs, B. Effect of magnesium supplementation on glucose metabolism in people with or at risk of diabetes: A systematic review and meta-analysis of double-blind randomized controlled trials. Eur. J. Clin. Nutr. 2016, 70, 1354-1359. [CrossRef] [PubMed]

51. Zheltova, A.A.; Kharitonova, M.V.; Iezhitsa, I.N.; Spasov, A.A. Magnesium deficiency and oxidative stress: an update. BioMedicine 2016, 6, 8-14. [CrossRef] [PubMed]

52. Barbagallo, M.; Dominguez, L.J. Magnesium and type 2 diabetes. World J. Diabetes 2015, 6, $1152-1157$. [CrossRef] [PubMed]

53. Instructions for Use. VITROS Chemistry Products Mg Slides. Available online: https://www.cmmc.org/ cmmclab/IFU/Mg_MP2-47_EN_I.pdf (accessed on 23 February 2017).

54. Lakshmanan, F.L.; Rao, R.B.; Kim, W.W.; Kelsay, J.L. Magnesium intakes, balances, and blood levels of adults consuming self-selected diets. Am. J. Clin. Nutr. 1984, 40, 1380-1389. [PubMed]

55. Misialek, J.R.; Lopez, F.L.; Lutsey, P.L.; Huxley, R.R.; Peacock, J.M.; Chen, L.Y.; Soliman, E.Z.; Agarwal, S.K.; Alonso, A. Serum and dietary magnesium and incidence of atrial fibrillation in whites and in African Americans: Atherosclerosis Risk in Communities (ARIC) Study. Circ. J. 2013, 77, 323-329. [CrossRef] [PubMed]

56. Bertinato, J.; Lavergne, C.; Plouffe, L.J.; El Niaj, H.A. Small increases in dietary calcium above normal requirements exacerbate magnesium deficiency in rats fed a low magnesium diet. Magnes. Res. 2014, 27, 35-47. [PubMed]

57. Bertinato, J.; Plouffe, L.J.; Lavergne, C.; Ly, C. Bioavailability of magnesium from inorganic and organic compounds is similar in rats fed a high phytic acid diet. Magnes. Res. 2014, 27, 175-185. [PubMed]

58. Klevay, L.M.; Milne, D.B. Low dietary magnesium increases supraventricular ectopy. Am. J. Clin. Nutr. 2002, 75, 550-554. [PubMed]

59. Witkowski, M.; Hubert, J.; Mazur, A. Methods of assessment of magnesium status in humans: A systematic review. Magnes. Res. 2011, 24, 163-180. [PubMed]

60. Song, Y.; He, K.; Levitan, E.B.; Manson, J.E.; Liu, S. Effects of oral magnesium supplementation on glycaemic control in type 2 diabetes: A meta-analysis of randomized double-blind controlled trials. Diabet. Med. 2006, 23, 1050-1056. [CrossRef] [PubMed]

61. Costello, R.B.; Elin, R.J.; Rosanoff, A.; Wallace, T.C.; Guerrero-Romero, F.; Hruby, A.; Lutsey, P.L.; Nielsen, F.H.; Rodriguez-Moran, M.; Song, Y.; et al. Perspective: The case for an evidence-based reference interval for serum magnesium: the time has come. Adv. Nutr. 2016, 7, 977-993. [CrossRef] [PubMed]

(C) 2017 by the authors. Licensee MDPI, Basel, Switzerland. This article is an open access article distributed under the terms and conditions of the Creative Commons Attribution (CC BY) license (http:/ / creativecommons.org/licenses/by/4.0/). 